\title{
Rotational atherectomy of right coronary artery complicated with stent dislodgment and ostial dissection - case report
}

Aterektomia rotacyjna prawej tętnicy wieńcowej powikłana zsunięciem stentu z cewnika balonowego i dysekcją ostium naczynia - opis przypadku

\author{
Wojciech Zimoch', Georg Gaul', Marcin Wojtczak', Piotr Kubler ${ }^{1,3}$, Krzysztof Reczuch ${ }^{1,3}$ \\ ${ }^{1}$ Center for Heart Diseases, Department of Cardiology, $4^{\text {th }}$ Military Clinical Hospital, Wroclaw, Poland \\ $2^{2}{ }^{\text {nd }}$ Department of Internal Diseases, Hanusch Hospital, Vienna, Austria \\ 3Department of Heart Diseases, Medical University of Wroclaw, Poland
}

Postep Kardiol Inter 2012; 8, 2 (28): 173-178

DOI: $10.5114 /$ pwki.2012.29661

\begin{abstract}
Highly calcified lesions in coronary arteries are a frequent cause of percutaneous coronary intervention failure. In such cases rotational atherectomy seems to be an efficient alternative that allows facilitation of the calcified atherosclerotic plaque and ensures successful treatment. We present a case of rotational atherectomy of the right coronary artery complicated with stent dislodgment and ostial dissection.
\end{abstract}

Key words: percutaneous coronary interventions, rotational atherectomy, stent dislodgment, dissection

\section{Streszczenie}

Silnie uwapnione zmiany w tętnicach wieńcowych są częstym powodem niepowodzenia przezskórnej angioplastyki. W takich przypadkach skuteczną alternatywą wydaje się aterektomia rotacyjna, która umożliwia modyfikację blaszki miażdżycowej i przeprowadzenie skutecznego zabiegu. Poniżej przedstawiamy przypadek rotablacji prawej tętnicy wieńcowej powikłanej zsunięciem się stentu z cewnika balonowego i dysekcją ostium naczynia.

Słowa kluczowe: przezskórne interwencje wieńcowe, aterektomia rotacyjna, zsunięcie stentu, dysekcja

\section{Introduction}

In daily practice interventional cardiologists are increasingly dealing with patients with highly calcified lesions in the coronary arteries. Optimal treatment of such lesions is often difficult or impossible and is associated with significant risk of treatment failure [1]. In this situation, rotational atherectomy (rotablation) seems to be an effective alternative. This method using a highly rotary diamond drill enables heavily calcified atherosclerotic plaques to be modified in a sufficient way to fully expand the balloon catheter at a safe pressure with subsequent optimal stent implantation.

Guidelines of the European Society of Cardiology (ESC) recommend rotablation as a method of "last resort" (bailout technique) in the case of lesions that cannot be crossed with a balloon or adequately expanded before stenting [2]. However, there are some reported cases of routine use of this technique to reduce the volume of atherosclerotic plaque before the angioplasty and in other indications, such as side-branch protection, support for the treatment of chronic total occlusions (CTO) or even in the treatment of in-stent restenosis [3].

Below we present a case of a patient with a long, highly calcified, critical stenosis of the right coronary artery diagnosed in our center which was treated with the use of rotablation complicated by slippage of the stent off the balloon catheter and dissection of the artery ostium. 


\section{Case report}

A 61-year-old man, non-smoker for 5 years (previously around 90 "pack years") with hypertension, type 2 diabetes, renal failure treated with long-term dialysis and kidney transplant 5 years earlier was admitted to the Department of Cardiology, $4^{\text {th }}$ Military Clinical Hospital in Wroclaw for coronary angiography. He had a history of about 2 years of typical exertional angina with increase of the symptoms severity in the last 2 months to CCS class III. Physical examination performed on admission revealed only an occluded vascular fistula on the left radial artery and an increased arterial pressure (to 150/90 $\mathrm{mm} \mathrm{Hg}$ ). Electrocardiography (ECG) revealed normal heart axis, regular sinus rhythm $65 / \mathrm{min}$, negative T wave in aVL lead and a higher by about $2 \mathrm{~mm}$ departure of the J point in leads V2-V4. Results of the laboratory tests did not show any abnormalities, and function of the transplanted kidney was normal (estimated glomerular filtration rate $[\mathrm{eGFR}]>60 \mathrm{ml} / \mathrm{min}$ ). Echocardiography demonstrated non-dilated cardiac chambers with preserved contractility and left ventricular ejection fraction (EF 65\%). Coronary angiography was performed via the right femoral artery in order to save the right radial artery and to maintain the possibility to perform another vascular shunt, in case of the need of repeated dialysis therapy. The study showed a normal left main coronary artery with massive calcifications extending to the proximal segments of the left anterior descending artery (LAD) and the circumflex artery (CX) visible on fluoroscopy, insignificant lesions in the LAD, 80\% stenosis in the middle segments of the $C x$ and a dominant right coronary artery (RCA) with a long, tortuous and heavily calcified $95 \%$ stenosis in the middle segment with normal flow of contrast to the peripheries of the vessel

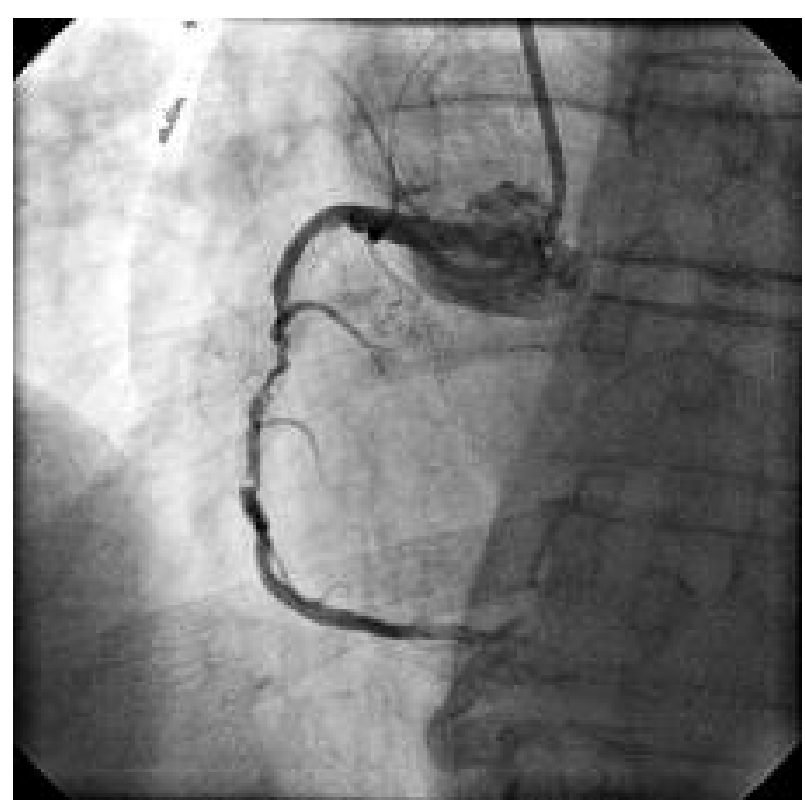

Fig. 1. Right coronary artery (LAO 28, CAUD 1) Ryc. 1. Prawa tętnica wieńcowa (LAO 28, CAUD 1)
(Figure 1). Heparin administration and ad hoc angioplasty were postponed because of the enlarging hematoma, which appeared during the study in the area of the vascular sheath. An attempt to perform angioplasty was made on the next day using the left femoral artery access. The ostium of the right coronary artery was intubated with a 6 F AL1 guiding catheter. It was impossible to cross the very tight and localized in a tortuous segment lesion with 0.014" BMW (Abbott Vascular) and Cruiser ES HF (Biotronik AG) guidewires, but it was possible with the hydrophilic Pilot 50 guidewire (Abbott Vascular). A balloon catheter $1.25 \mathrm{~mm} \times 10 \mathrm{~mm}$ (Sapphire II, OrbusNeich) was introduced inside the lesion with great difficulty and because of the presence of massive calcifications it was only partially expanded. It was impossible to introduce a larger balloon catheter $(1.5 \mathrm{~mm} \times 14 \mathrm{~mm}$, Avion Plus, Invatec) through the proximal part of the lesion. A decision to perform rotablation was taken. Because of the accompanying kidney disease and high consumption of contrast (150 ml of Ultravist, Bayer Healthcare) rotablation was postponed and the patient was qualified for an elective procedure after the implementation of contrastinduced nephropathy prevention. He was admitted 7 days later and after adequate hydration and control of renal parameters underwent the rotablation procedure through the right radial artery. The procedure was performed without the back-up of temporary electro-stimulation by the decision of the operator. The ostium of the right coronary artery was intubated with an AL1 6F catheter (Launcher, Medtronic) and after numerous and painstaking attempts the rotablation guidewire (RotaWire Floppy, Boston Scientific) was introduced to the peripheries of the artery. Because of the long and tight stenosis and massive calcifications a "step-up" technique was used - initial passages were performed using a $1.25 \mathrm{~mm}$ diameter and then $1.5 \mathrm{~mm}$ diameter drill (RotaLink Plus, Boston Scientific) at 140000 rotations per min (Figure 2). After achievement of full inflation of balloons $-2.5 \mathrm{~mm} \times 30 \mathrm{~mm}$ (Avion Plus, Invatec) at $14 \mathrm{~atm}$ and $3.5 \mathrm{~mm} \times 20 \mathrm{~mm}$ (Sprinter Legend, Medtronic) at $12 \mathrm{~atm}$ - the guidewire was switched to Cruiser ES-HF (Biotronik AG) and used to implant two overlapping stents in the distal and middle segment - respectively $3.5 \mathrm{~mm} \times 38 \mathrm{~mm}$ at $14 \mathrm{~atm}$ and $4.0 \mathrm{~mm} \times 24 \mathrm{~mm}$ at $14 \mathrm{~atm}$ (Promus, Boston Scientific) with post-dilation of the overlapping parts at 16 atm (Figure 3). Due to incomplete coverage of the proximal part of the lesion it was decided to implant another stent, $4.0 \mathrm{~mm} \times 16 \mathrm{~mm}$ (Promus, Boston Scientific). Initial attempts to cross the lesion with the stent failed and to gain extra support the operator decided to deeply intubate the ostium of the right coronary artery. At that time the stent slipped off the balloon catheter (after contact with the tip of the guiding catheter) (Figure 4). The stent migrated to the middle segment of the vessel, but remained anchored on the guidewire. Therefore, it was decided that the safest method of its evacuation was to 


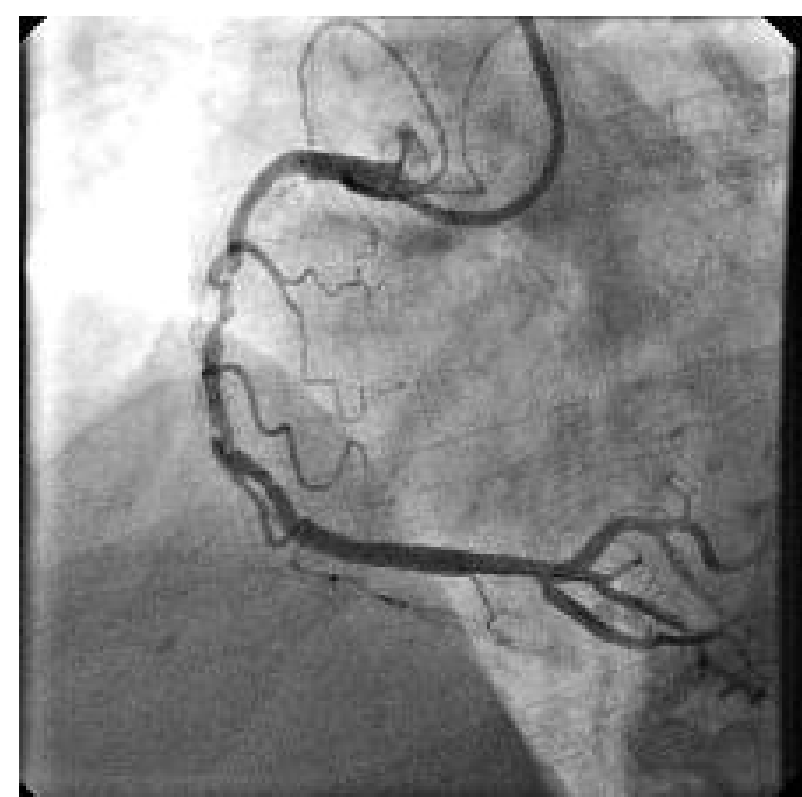

Fig. 2. Status after passages with $1.25 \mathrm{~mm}$ and $1.5 \mathrm{~mm}$ drills (LAO 34, CAUD 2)

Ryc. 2. Stan po pasażach wiertłami $1,25 \mathrm{~mm}$ i 1,5 mm (LAO 34, CAUD 2)

attempt to reintroduce the balloon into the stent. After many attempts a $1.25 \mathrm{~mm} \times 6 \mathrm{~mm}$ balloon catheter (Sapphire II, OrbusNeich) was successfully reintroduced into the stent and used to pull back and partially expand the stent (Figure 5). Because of the risk of peripheral embolism the stent was not completely evacuated. Instead

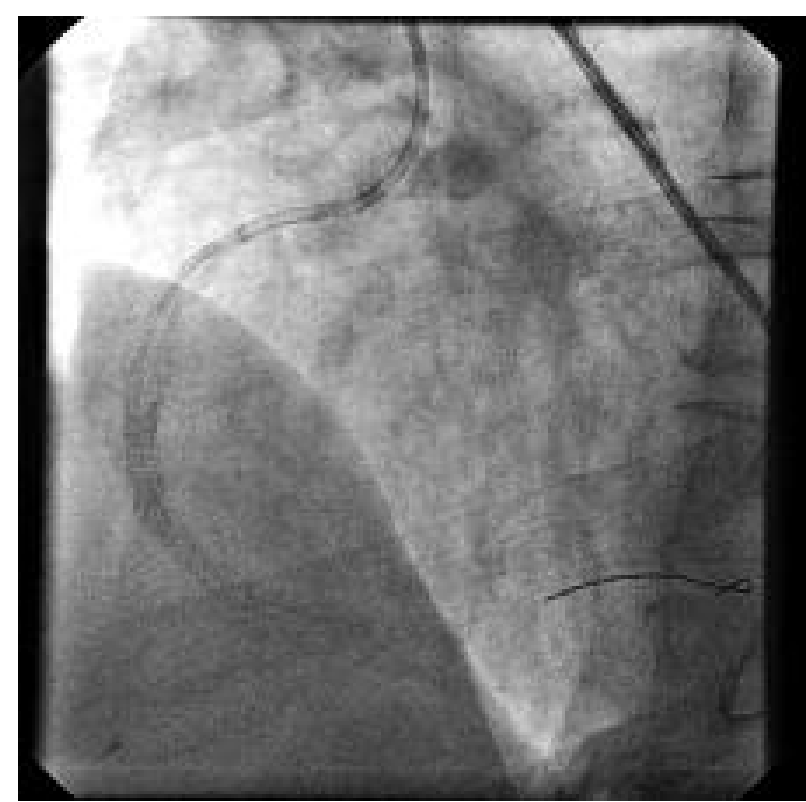

Fig. 4. The stent that slipped off the balloon catheter visible in the proximal segment of the vessel (LAO 34, CAUD 2)

Ryc. 4. W odcinku proksymalnym naczynia widoczny stent zsunięty z cewnika balonowego (LAO 34, CAUD 2)

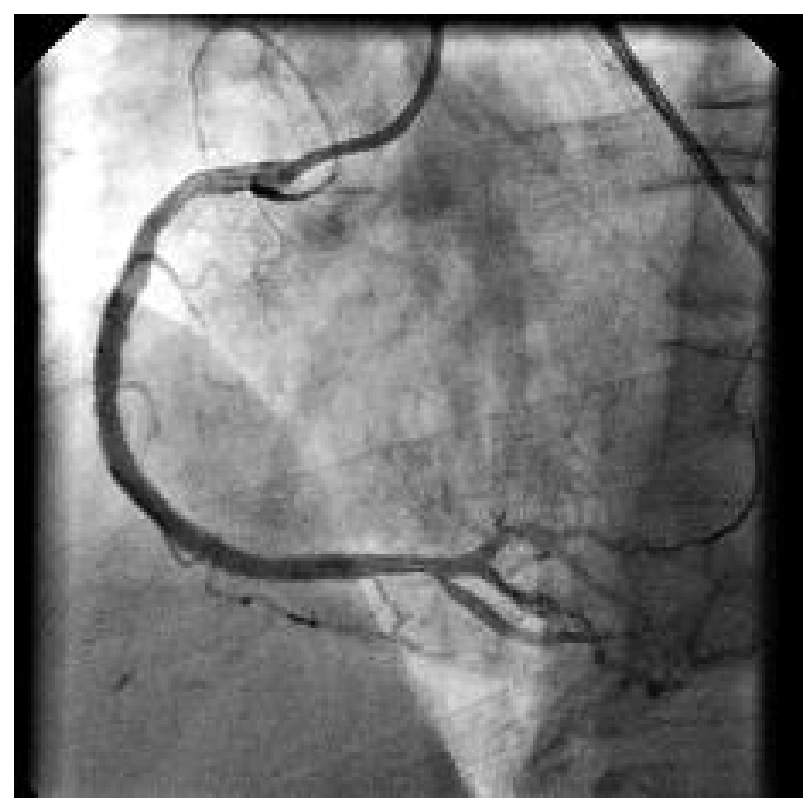

Fig. 3. Status after implantation of 2 DES (LAO 34, CAUD 2)

Ryc. 3. Stan po implantacji 2 stentów DES (LAO 34, CAUD 2)

it was expanded inside the previously implanted stent using successively $1.5 \mathrm{~mm} \times 15 \mathrm{~mm}, 2.0 \mathrm{~mm} \times 15 \mathrm{~mm}$, $2.5 \mathrm{~mm} \times 15 \mathrm{~mm}, 3.0 \mathrm{~mm} \times 15 \mathrm{~mm}, 4.0 \mathrm{~mm} \times 15 \mathrm{~mm}$ bal loon catheters (Sprinter Legend, Medtronic). Finally, a postdilation with a $4.0 \mathrm{~mm} \times 15 \mathrm{~mm}$ balloon catheter (Quantum Maverick, Boston Scientific) at $18 \mathrm{~atm}$ was made to

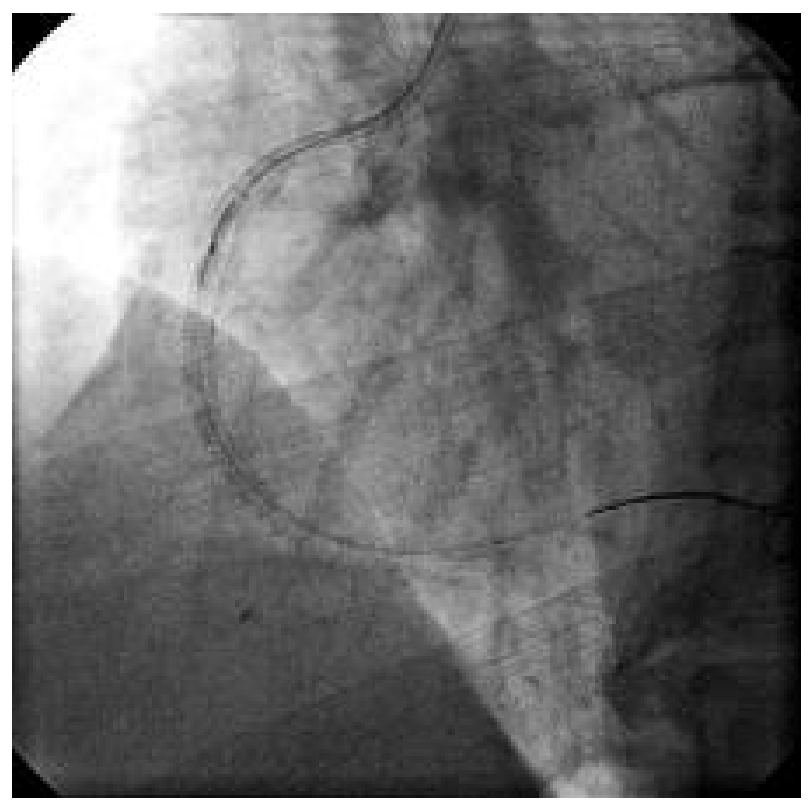

Fig. 5. Balloon catheter $(1.25 \mathrm{~mm})$ expanded inside of the stent (LAO 34, CAUD 2)

Ryc. 5. Rozprężony cewnik balonowy $1,25 \mathrm{~mm}$ wewnątrz stentu (LAO 34, CAUD 2) 


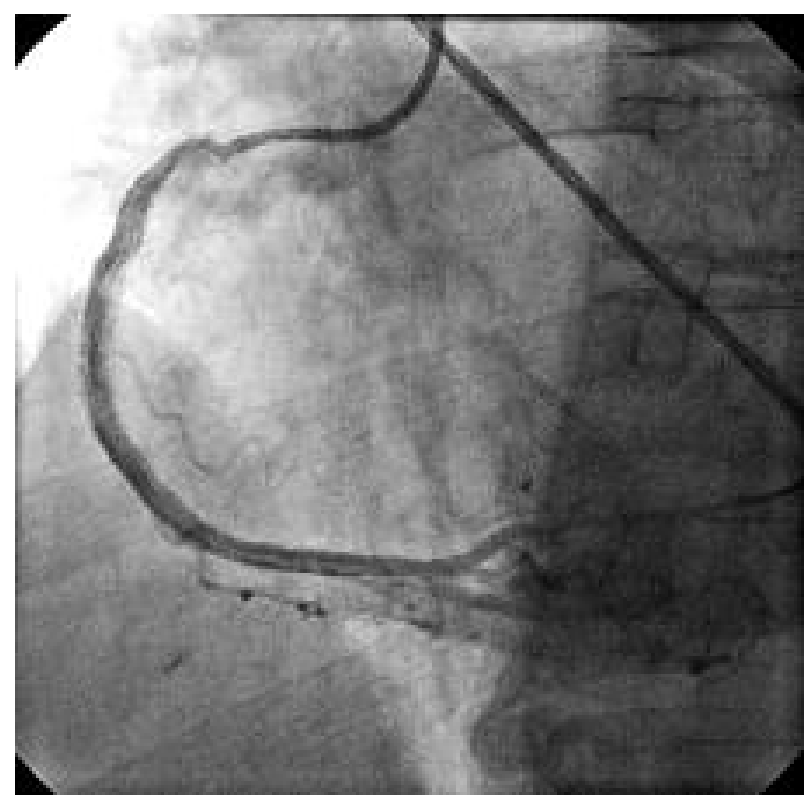

Fig. 6. Status after implantation of 3 DES. Visible dissection of the vessel ostium (LAO 34, CAUD 2) Ryc. 6. Stan po implantacji 3 stentów DES. Widoczna dysekcja ostium naczynia (LAO 34, CAUD 2)

obtain the correct apposition of the stent. Because of the dissection in the proximal segment of the vessel it was necessary to implant another $4.0 \mathrm{~mm} \times 20 \mathrm{~mm}$ stent (Promus, Boston Scientific) at 16 atm directly into the ostium of the RCA (Figure 6). Post-dilation was performed with a $4.0 \mathrm{~mm} \times 15 \mathrm{~mm}$ balloon catheter (Quantum Maverick, Boston Scientific) at 18 atm. Optimal results were obtained with the full expansion of the treated vessel and normal TIMI 3 flow (Figure 7).

Total time of the procedure was $2 \mathrm{~h} 45 \mathrm{~min}$, fluoroscopy time $48 \mathrm{~min} 39 \mathrm{~s}$. The dose of radiation was $1123 \mathrm{mGy}$. $250 \mathrm{ml}$ of contrast and $8000 \mathrm{IU}$ of heparin were administered. After treatment, there was an increase of myocardial necrosis markers (high-sensitivity troponin I [Tnl]) to $1.26 \mathrm{ng} / \mathrm{ml}$ on the day of the procedure, with its gradual fall and normalization at day 3. There were no complications during subsequent hospitalization and no significant increase in serum creatinine level or renal dysfunction. Symptoms of angina have disappeared. The patient was discharged on the $3^{\text {rd }}$ day after the recommendation of adoption of the following drugs: clopidogrel $(1 \times 75 \mathrm{mg}$ for 12 months), acetylsalicylic acid $(1 \times 75 \mathrm{mg})$, atorvastatin (1 × $40 \mathrm{mg})$, bisoprolol $(1 \times 5 \mathrm{mg})$, nitrendipine $(2 \times 10 \mathrm{mg})$, extended-release gliclazide $(1 \times 30 \mathrm{mg})$, cyclosporine (75 mg morning, 60 mg evening), mycophenolate mofetil $(3 \times 500 \mathrm{mg})$, prednisone $(1 \times 5 \mathrm{mg})$.

\section{Discussion}

Suboptimal expansion of the balloon catheter, which is often observed during angioplasty of highly calcified lesions, causes mild increase of the vessel diameter but at

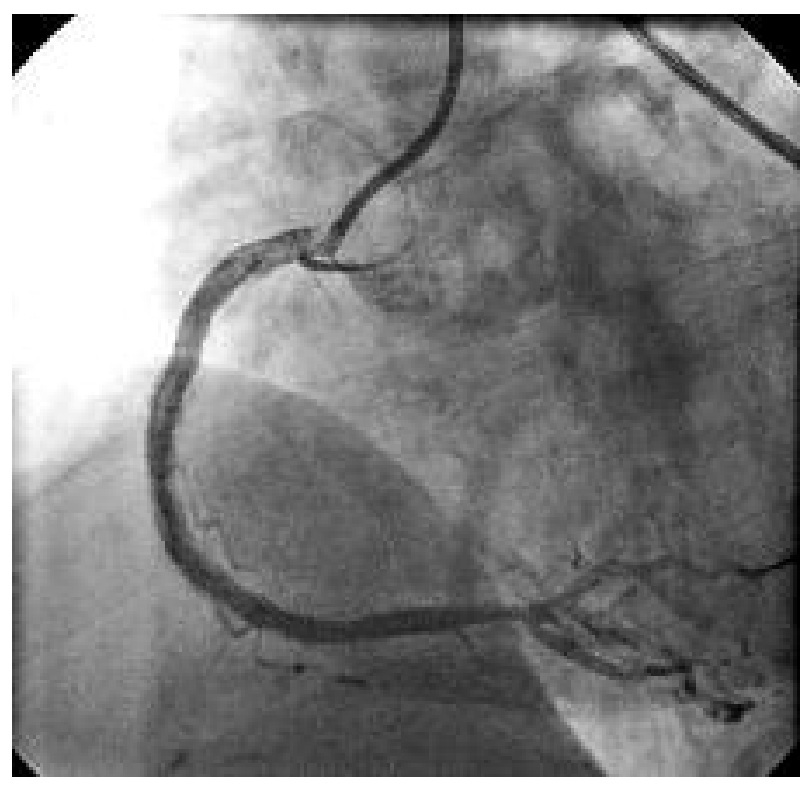

Fig. 7. Final effect of the procedure (LAO 29, CAUD 2) Ryc. 7. Efekt końcowy zabiegu (LAO 29, CAUD 2)

the same time a large injury to the endothelium [4]. An attempt to expand the artery "at all costs" by using highpressure non-compliant balloons (above $20 \mathrm{~atm}$ ) may end with rupture of the balloon or the occurrence of the socalled hourglass phenomenon - an excessive expansion of the balloon catheter directly before and after the lesion with a risk of an extensive dissection and even perforation of the vessel. Therefore in our center patients in whom balloon angioplasty using relatively safe pressures (about $16 \mathrm{~atm}$ ) was ineffective are qualified for the rotablation procedure, which is consistent with the ESC guidelines [2]. Rotablation procedures are often performed ad hoc, but it should be noted that they are associated with an additional radiation exposure and the use of larger amounts of the contrast medium, which, taking into account the patient's history, was a decisive factor for postponement of the procedure until implementation of the optimal prevention of contrast-induced nephropathy (CIN). The efficacy of a rotational atherectomy has been demonstrated in several studies, but most of them were performed before the era of drug-eluting stents (DES) [5]. In the "era of DES" there has been only one randomized study, which is not yet published - the ROTAXUS study [6]. The study did not demonstrate an advantage of rotablation over standard balloon angioplasty with DES implantation (Taxus, Boston Scientific) in the treatment of heavily calcified lesions. The discussion of the results of this study is beyond the scope of this paper, but it should be noted that in the opinion of the experts, the study has confirmed the previous recommendation of the ESC to consider rotablation as a "last chance" procedure after unsuc- 
cessful balloon angioplasty. Many of the technical aspects of the rotablation procedures still inspire debate. The use of temporary pacing during procedures on the right coronary artery, until recently, was considered mandatory. This was associated with reports of high incidence of microvascular embolization with particles detaching from the atherosclerotic plaque during the procedure and the related "no-reflow" phenomenon [7]. Currently, the passage of the drill is accompanied by administration of an intracoronary "cocktail" of vasodilative drugs and heparin, which significantly reduce the risk of this phenomenon and symptomatic bradycardia and allow one to safely perform the procedure without the need to introduce an electrode into the right ventricle, as in the described patient [6]. The CARAT study compared two strategies of drill diameter selection for the procedure: the direct application of a large drill (ratio of drill diameter to vessel diameter $>0.7$ ) and the use of several drills with gradual increase of their diameter so that the drill/vessel ratio always remained below 0.7 (the "step-up" technique). None of these methods showed an advantage in the long-term follow-up, but the "step-up" technique was associated with a lower incidence of procedural complications (5.1\% vs. $12.7 \%$ ) [8]. The complex morphology of the lesion in the described patient led us to apply this particular strategy. It should be noted that in more than $90 \%$ of the cases from the ROTAXUS study the optimal effect of treatment was achieved using only one size of drill (usually $1.5 \mathrm{~mm}$ ). This did not lead to an increased number of complications [6]. These results, together with the obvious economic aspect, make this strategy a routine one in our department. Another debatable aspect is the selection of the speed at which the drill rotates during the procedure. Recommended speeds are within the limits of $140000-180000 / \mathrm{min}$. In the ROTAXUS study a high drill speed (170 000/min) was used and the "no-reflow" phenomenon was not observed in any of the 120 patients [6]. In vitro studies showed, however, that a high drill speed (180 000/min) could cause platelet activation and thereby contribute to the intensity of the "no-reflow" phenomenon $[9,10]$. It should be emphasized that this phenomenon occurs more frequently during procedures on long lesions with a complex morphology, as in the described patient [11]. In the present case, the operator following personal experience applied lower speeds with tight control of drill rotation. Studies with bare metal stents proved in fact that decreases in drilling speed during the passage exceeding 5000 rotations per minute are associated with an increased risk of restenosis [12]. No significant drops in rotational speed of the drill were noted during the presented procedure. In the described patient an access via the radial artery was used to avoid recurrence of bleeding complications at the site of femoral artery puncture. It has been shown that it is a safe and effective way to conduct this type of procedure $[13,14]$.
Slippage of the stent off the balloon catheter is a rare complication of coronary angioplasty procedures. In view of the mechanical mounting of stents and increased operator experience the incidence of this complication is decreasing and now occurs in approximately $0.32 \%$ of procedures [15]. Risk factors can be divided into those depending on the operator (experience, technique of the procedure), the patient (heavily calcified lesions in the proximal part of the vessel, tortuosity of the lesion) and the equipment (the method of stent crimping, guiding catheter support) [16]. Although these risk factors are present more often during a rotablation procedure in comparison to the "classic" angioplasty, the authors failed to find a description of such a complication during a rotablation procedure in the literature. It should be noted that rotablation does not entirely remove the plaque, but only modifies it, so despite repeated passages with the drill there might still be calcified fragments of the atherosclerotic plaque protruding into the vessel lumen and obstructing the passage of the stent. That was the case in the patient described by us. To increase the support of the guiding catheter the operator introduced it deeply into the proximal segment of the vessel, which could cause stent slippage and dissection. In similar situations, Garg et al. suggest a deep intubation directly before the stenosis using a $5 \mathrm{~F}$ catheter introduced through the $6 \mathrm{~F}$ catheter, but it is also possible to use a dedicated guiding catheter (GuideLiner, Vascular Solutions, Inc.) [17]. These methods enable one to perform a successful angioplasty via the radial access, even in extremely technically difficult cases [18]. Removal of a slipped stent is possible after its reintroduction on the balloon catheter followed by balloon expansion and withdrawal of the whole set outside of the body, but also using techniques based on twisting of the two guidewires, the lasso loop or dedicated forceps (for use outside of the coronary arteries). Suboptimal solutions include compression of the failed stent to the vessel wall with another stent or urgent coronary artery bypass graft (CABG) (necessary in about $5 \%$ of cases) $[15,16]$. Despite the high technical difficulty these treatment strategies are effective in approximately $86 \%$ of cases [15]. Leaving the improperly expanded stent increases the risk of stent thrombosis, myocardial infarction, peripheral embolism and sometimes stroke and in rare cases may even end with a fatal outcome [16]. In the present case we chose the safest indirect option for the patient: complete evacuation of the stent appeared to be too dangerous, so the operator decided to expand the stent inside of the previously implanted stent (after balloon insertion inside the slipped stent and its maximal pull-back), and therefore part of the vessel was covered with two layers of stents (a so-called "stent sandwich"). A similar situation is encountered during therapy of in-stent restenosis using drug-eluting stents, where it has been proved safe for the patient [19]. Dissection of the vessel wall is anoth- 
er complication of coronary angioplasty. Risk factors for iatrogenic vascular injury include the type and diameter of the guiding catheter used, anatomical variant of the vessel ostium, the use of high pressures during balloon angioplasty, and vigorous administration of contrast [20]. In the present case the dissection was caused by deep intubation with the guiding catheter. The Amplatz Left catheter used during the procedure provides good support, but increases the risk of iatrogenic injury of the right coronary artery ostium [20]. Dissection in this location may result in its extension to the aorta and therefore urgent treatment with stent implantation is needed [20]. This procedure is particularly technically difficult, because it requires positioning of the stent "off air" with the guiding catheter retracted from the ostium of the artery and placed in the aorta. In our case, the dissection included a small segment of the vessel located proximally to the previously implanted stents and was treated with $4.0 \mathrm{~mm} \times 20 \mathrm{~mm}$ stent implantation (Promus, Boston Scientific).

The increasing number of patients with massive calcifications in the coronary arteries may require a rotablation procedure and therefore this technique should be available in major centers of invasive cardiology ("high volume centers") to ensure comprehensive care of patients. This case shows that even in extremely difficult and complicated case of rotablation, it is possible to obtain the optimal effect of treatment for the patient.

\section{References}

1. Tan K, Sulke N, Taub N, et al. Clinical and lesion morphologic determinants of coronary angioplasty success and complications: current experience. J Am Coll Cardiol 1995; 25: 855-865.

2. Taggart DP, Boyle R, de Belder MA, et al. The 2010 ESC/EACTS guidelines on myocardial revascularisation. Heart 2011; 97 : 445-446.

3. Schwartz BG, Mayeda GS, Economides C, et al. Rotational atherectomy in the drug-eluting stent era. J Inv Cardiol 2011; 23: 133-139.

4. Kuntz RE, Safian RD, Carrozza JP, et al. The importance of acute luminal diameter in determining restenosis after coronary atherectomy or stenting. Circulation 1992; 86: 1827-1835.

5. Reifart N, Vandormael M, Krajcar M, et al. Randomized comparison of angioplasty of complex coronary lesions at a single center Excimer Laser, Rotational Atherectomy, and Balloon Angioplasty Comparison (ERBAC) study. Circulation 1997; 96: 91-98.

6. Richardt G. ROTAXUS: a prospective, randomized trial of highspeed rotational atherectomy prior to paclitaxel-eluting stent implantation in complex calcified coronary lesions. Presented at: Transcatheter Cardiovascular Therapeutics 2011; November 11, 2011; San Francisco, CA.

7. Saland KE, Cigarroa JE, Lange RA, et al. Rotational atherectomy. Cardiol Rev 2000; 8: 174-179.

8. Safian RD, Feldman T, Muller DW, et al. Coronary Angioplasty and Rotablator Aherectomy Trial (CARAT): immediate and late results of a prospective multicenter randomized trial. Catheter Cardiovasc Interv 2001; 53: 213-220.

9. Williams MS, Coller BS, Väänänen HJ, et al. Activation of platelets in platelet-rich plasma by rotablation is speed-dependent and can be inhibited by abciximab (c7E3 Fab; ReoPro). Circulation 1998; 98: 742-748.

10. Reisman M, Shuman BJ, Dillard D, et al. Analysis of low-speed rotational atherectomy for the reduction of platelet aggregation. Cathet Cardiovasc Diagn 1998; 45: 208-214.

11. Morii I, Miyazaki S. Current overview of rotational atherectomy. Does rotablator make sense? Emodinamica 2000; 22: 2-9.

12. Whitlow PL, Bass TA, Kipperman RM, et al. Results of the study to determine rotablator and transluminal angioplasty strategy (STRATAS). Am J Cardiol 2001; 87: 699-705.

13. Watt J, Oldroyd KG. Radial versus femoral approach for high Speed rotational atherectomy. Catheter Cardiovasc Interv 2009; 74: 550-554.

14. Gioia G, Comito C, Moreyra AE. Coronary rotational atherectomy via transradial approach: a study using radial artery intravascular ultrasound. Catheter Cardiovasc Interv 2000; 51: 234-238.

15. Brilakis ES, Best PJ, Elesber AA, et al. Incidence, retrieval methods, and outcomes of stent loss during percutaneous coronary intervention: a large single-center experience. Catheter Cardiovasc Interv 2005; 66: 333-340.

16. Ngow H. Stent dislodgement in left anterior descending coronary artery and successful deployment with two parallel wires and a small balloon. Kardiol Pol 2009; 67: 1040-1042.

17. Garg S, Schultz C, Sarno G, et al. How should I treat a tortuous calcified right coronary artery? Eurolntervention 2010; 6: 161-167.

18. Pershad A, Sein V, Laufer N. GuideLiner catheter facilitated PCI: a novel device with multiple applications. J Invasive Cardiol 2011; 23: E254-9.

19. Mehilli J, Byrne RA, Tiroch K, et al. Randomized trial of paclitaxelversus sirolimus-eluting stents for treatment of coronary restenosis in sirolimus-eluting stents: the ISAR-DESIRE 2 (Intracoronary Stenting and Angiographic Results: Drug Eluting Stents for In-Stent Restenosis 2) study. J Am Coll Cardiol 2010; 55: 2710-2716.

20. Sohrabi B, Kazemi B, Aslanabadi N. Percutaneous treatment of catheter-induced dissection of the right coronary artery and adjacent aortic wall. J Invasive Cardiol 2007; 19: E199-E202. 